\title{
The Library in the Information Ecosystem of Open Science
}

\author{
N. S. Redkina* \\ State Public Scientific Technological Library, Siberian Branch, Russian Academy of Sciences, Novosibirsk, Russia \\ *e-mail: redkina@spsl.nsc.ru \\ Received August 5, 2021
}

\begin{abstract}
The results of an analysis of trends in the development of the information ecosystem of open science based on the study of the global document flow, open access resources, and scientific data repositories, as well as initiatives in the field of open science, including during the COVID-19 pandemic, are presented. The directions of activity of libraries in these conditions are determined.
\end{abstract}

Keywords: libraries, open science, information ecosystem, librarian competence, open access, repositories, scientific data, information resources

DOI: $10.3103 / \mathrm{S} 0147688221040043$

\section{INTRODUCTION}

Initiatives supporting the development of open science, the availability of data for the entire scientific community, as well as the transparency and reproducibility of research results, are gaining increasing recognition in the world, leading to significant changes in the infrastructure of scientific communications, the principles and methods of conducting scientific work, the recording and promoting of their results, as well as suggesting new solutions to problems related to improving the quality, support, and dissemination of scientific research. This information infrastructure of open science (open access resources, open educational resources, open research data in repositories, etc.), increases the transparency of the research process on the one hand; on the other hand, it modifies traditional social institutions and mechanisms and modifies the market of information resources and services, setting new rules, conditions, and prospects.

\section{DEVELOPMENT OF THE ECOSYSTEM OF OPEN SCIENCE}

Open science initiatives are promoted by various science foundations, national research councils, and government agencies (e.g., European Commission, Center for Open Science, FORCE11, and the Wellcome trust), as well as numerous university and national communities, major publishers and consortia; they have an impact on the formation of the ecosystem of science. UNESCO prepared a roadmap for the development of Recommendations [1], in which it is planned to establish standards aimed at forming a coherent vision of Open Science.
FAIR Principles (findable, accessible, interoperable, and re-usable $)^{1}$ and international initiatives in the field of open science are implemented in the recommendations of the publishing houses of scientific journals on providing access to primary data, on the openness of peer review, and in the requirements of scientific foundations on the openness of data as a prerequisite for obtaining international and national grants. Among these requirements is open access to published materials [2].

The number of organizations and projects that fund research is growing, as is the number of articles. In the process of searching for organizations funding scientific research, whose results were presented in the public domain in 2016-2020 and are reflected in the Scopus database, we have identified a list of the most common ones (Table 1), among which the scientific foundations of China, Japan, the United States, the European Union, and the United Kingdom prevail.

Depending on the subject area, the list of funding organizations changes. Thus, in the field of social and human sciences, the most common funding organizations are the National Institutes of Health, U.S. Department of Health and Human Services, European Commission, National Science Foundation, National Natural Science Foundation of China, UK Research and Innovation, Horizon 2020 Framework Program, Economic and Social Research Council, and, in the field of natural and technical sciences, such specialized organizations as the U.S. Department of

\footnotetext{
${ }^{1}$ FAIR (findable, accessible, interoperable and re-usable): findable (findability) - easy search for specific datasets, accessible (availability) - convenient access (according to access conditions and storage possibilities) for a long time, interoperable (interoperability)-compatibility with other datasets or software, reusable (reuse)-reusable (re) use in further research.
} 
Table 1. List of most frequently met funding organizations the results of which are presented open access in 2016-2020 and indexed in Scopus. Query PUBYEAR > 2015 AND (LIMIT-TO (OA, “all”))

\begin{tabular}{|c|c|}
\hline Funding organization (sponsor/foundation/program) & $\begin{array}{c}\text { Number of publications } \\
\text { in Scopus from } 2016 \text { to } 2020\end{array}$ \\
\hline National Natural Science Foundation of China & 491097 \\
\hline National Institutes of Health & 459398 \\
\hline U.S. Department of Health and Human Services & 387260 \\
\hline National Science Foundation & 240915 \\
\hline European Commission & 222544 \\
\hline Horizon 2020 Framework Programme & 136912 \\
\hline Japan Society for the Promotion of Science & 134283 \\
\hline Ministry of Education, Culture, Sports, Science and Technology & 127394 \\
\hline UK Research and Innovation & 123552 \\
\hline Deutsche Forschungsgemeinschaft & 101319 \\
\hline National Cancer Institute & 89921 \\
\hline Seventh Framework Programme & 87110 \\
\hline U.S. Department of Energy & 85732 \\
\hline European Research Council & 84713 \\
\hline Ministry of Science and Technology of the People's Republic of China & 76334 \\
\hline National Institute of General Medical Sciences & 73406 \\
\hline Engineering and Physical Sciences Research Council & 72975 \\
\hline European Regional Development Fund & 65039 \\
\hline National Research Foundation of Korea & 62529 \\
\hline National Key Research and Development Program of China & 60873 \\
\hline Government of Canada & 59170 \\
\hline Conselho Nacional de Desenvolvimento Científico e Tecnológico & 58637 \\
\hline National Heart, Lung, and Blood Institute & 56839 \\
\hline Fundamental Research Funds for the Central Universities & 55992 \\
\hline Ministry of Education of the People's Republic of China & 55698 \\
\hline U.S. Department of Defense & 54793 \\
\hline Medical Research Council & 53120 \\
\hline National Institute of Allergy and Infectious Diseases & 50407 \\
\hline
\end{tabular}

Energy, Japanese Society for the Promotion of Science, and the Engineering and Physical Sciences Research Council.

The emergence of open access (OA) initiatives is transforming the traditional scientific communication environment and is driving an increase in the number of open access journals and research articles. According to some reports [3], the share of OA in scientific literature is already estimated at 27\% (approximately 19 million articles in total) and is growing mainly due to the golden and hybrid versions of the OA model, while it is noted that open access articles are cited $18 \%$ more than articles are on average; this effect is mainly provided by the green and hybrid variants of OA.

Our bibliometric analysis in the field of Social Sciences, including subject areas such as Arts and Humanities (ARTS); business, management, and accounting (BUSI); Decision Science (DECI); Economics, Econometrics, and Finance (ECON); Psychology (PSYC); Social Sciences (SOCI), indicates a further increase in the flow of open access publications. At the time of collecting the information, the total volume of open access publications reflected in the Scopus database for 2012-2020 was 1184815 documents; their share in the total document flow in this branch of knowledge in 2020 exceeded 30\% (Fig. 1).

The proliferation of open science initiatives is also shown by the emergence of an increasing number of open access resources: full-text and factual (Open DOAR, ScienceOpen, CORE, PubMed Central, arXiv, BioMed Central, DOAJ, Education Resources Information Center (ERIC), Bentham Open, PLOS, Hindawi, Springer Open, Science Direct, NISCAIR, DOAB, CyberLeninka, Socionet archive, a number of 


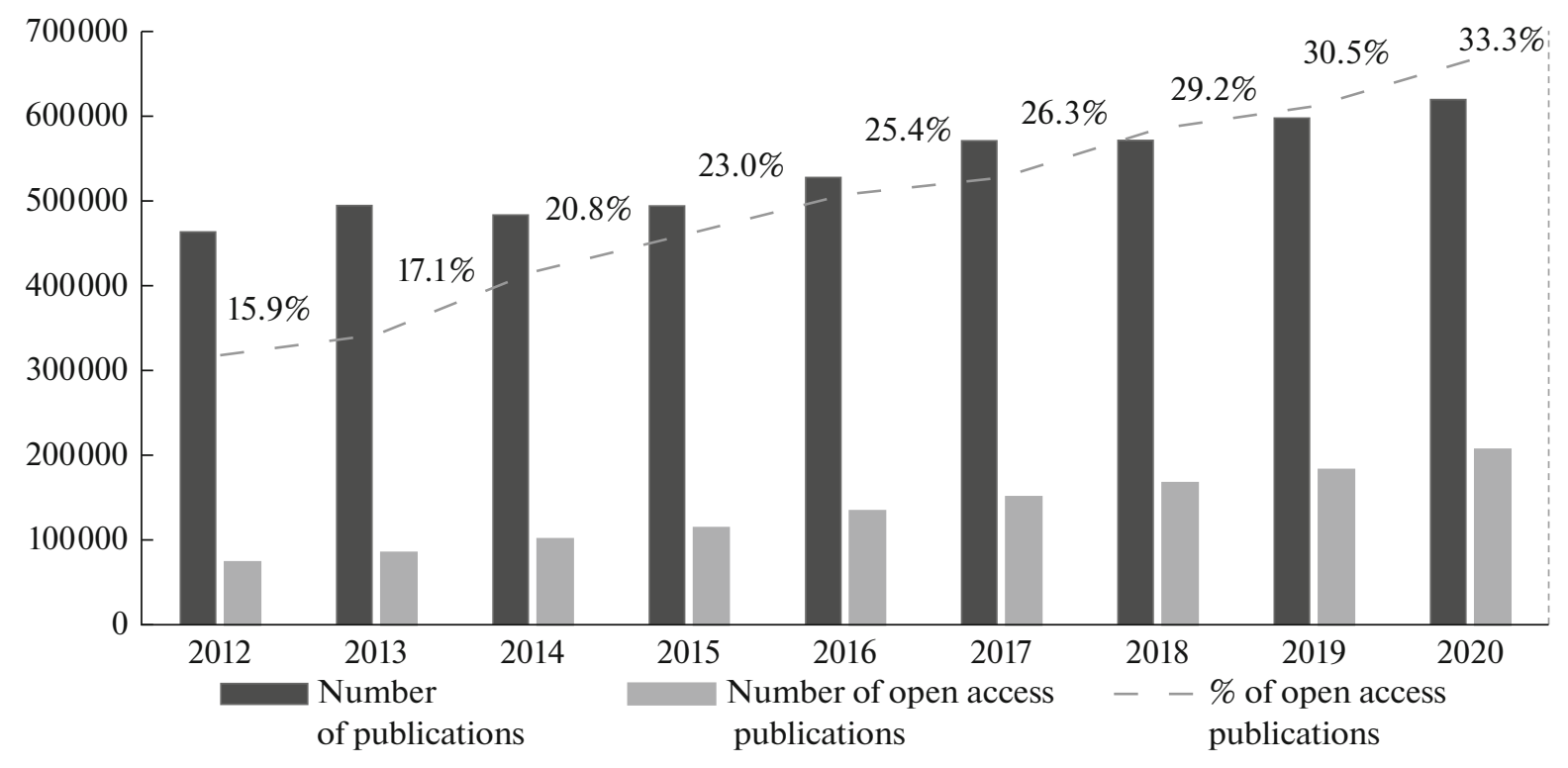

Fig. 1. Dynamics of growth in the number of open access publications indexed in Scopus (2012-2020) in the area of social sciences.

projects of the nonprofit partnership (NP) National Electronic Information Consortium (NEICON), the elpub magazine platform, the preprints.ru preprint server, the national aggregator of open repositories (NORA), etc. The growing number of institutional repositories and open access publishing models are also helping to advance this approach, which improves access to the results of scientific research, promotes integration of scientists to the world scientific community, avoids duplication and promptly verify research results, and accelerates innovation and development of individual institutions and countries.

In early 2019 , the global registry for research data warehouses (re3data.org) submitted 2250 repositories (1869 industry-specific and 563, institutional), of which humanities and social sciences equaled 689 per year, life sciences, 1207; natural sciences, 1110; technical sciences, 339; etc. In 2021, the number of repositories increased to 3108 (2113, industry-specific; 701, institutional; and 294, other). As the analysis shows, most of the data in the storages reflects scientific and statistical information, standard documents prepared in MS Office, images, etc. The leader in the number of such data warehouses is the United States (Table 2), 1119 (in 2019-1035). The number of international storage facilities has increased over 2 years, Russia is in 21st place in this rating; the number of storage facilities in which Russian research data are presented is 22 (this was unchanged compared to 2019).

In the re3data.org registry, research data are presented for almost all scientific disciplines. However, repositories with data on life sciences (biology, medicine, agriculture, etc.) equaled 1473; natural sciences (chemistry, physics, mathematics, earth sciences, geo- physics and geodesy, computer science, electrical engineering, etc.), 1349; humanities and social sciences, including the humanities in general, history, economics, linguistics, etc., 951. The distribution of repositories by the most developing subject areas is presented in Table 3. In 2021, data on COVID-19 appeared in 68 repositories (in the subject areas of clinical trials, biochemistry, epidemiology, etc.).

The critical importance of international scientific cooperation, free access to scientific data, research results, educational resources, and research facilities

Table 2. Distribution of databanks by geography in re3data.org

\begin{tabular}{l|c|c}
\hline \multirow{2}{*}{\multicolumn{1}{c|}{ Country }} & \multicolumn{2}{|c}{ Years } \\
\cline { 2 - 3 } & 2021 & 2019 \\
\hline USA & 1119 & 1035 \\
Germany & 457 & 347 \\
United Kingdom & 305 & 295 \\
European Union & 283 & 201 \\
Canada & 259 & 186 \\
International & 254 & 214 \\
France & 116 & 98 \\
Australia & 94 & 35 \\
Switzerland & 80 & 68 \\
Netherlands & 62 & 52 \\
Japan & 61 & 56 \\
India & 51 & 49 \\
China & 48 & 40 \\
\hline
\end{tabular}


Table 3. Distribution of repositories over subject areas in re3data.org in 2021 (fragment of most frequently met subject areas)

\begin{tabular}{|c|c|}
\hline Subject area & $\begin{array}{c}\text { Number } \\
\text { of repositories }\end{array}$ \\
\hline Biology & 900 \\
\hline Earth sciences, including geography & 772 \\
\hline Medicine & 630 \\
\hline Fundamental biology and medicine & 523 \\
\hline Engineering & 515 \\
\hline Social and behavioral sciences & 441 \\
\hline Atmospheric science and oceanography & 410 \\
\hline Medicine & 401 \\
\hline Humanitarian sciences & 312 \\
\hline Physics & 312 \\
\hline Social Sciences & 290 \\
\hline Geophysics and geodesy & 262 \\
\hline Zoology & 244 \\
\hline General genetics & 222 \\
\hline Chemistry & 221 \\
\hline Microbiology, virology, and immunology & 218 \\
\hline Botany & 215 \\
\hline Economy & 207 \\
\hline $\begin{array}{l}\text { Agriculture and forestry, horticulture, } \\
\text { and veterinary science }\end{array}$ & 193 \\
\hline Astrophysics and astronomy & 179 \\
\hline Bioinformatics and theoretical biology & 176 \\
\hline Oceanography & 172 \\
\hline Geography & 160 \\
\hline $\begin{array}{l}\text { Informatics, electrotechnics, and systems } \\
\text { engineering }\end{array}$ & 149 \\
\hline Water studies & 144 \\
\hline Public health studies and social medicine & 133 \\
\hline Atmospheric science & 131 \\
\hline $\begin{array}{l}\text { Agriculture and forestry, horticulture, } \\
\text { and veterinary science }\end{array}$ & 129 \\
\hline Human genetics & 117 \\
\hline Linguistics & 106 \\
\hline History & 103 \\
\hline Empirical social studies & 103 \\
\hline $\begin{array}{l}\text { Geodesy, photogrammetry, remote sens- } \\
\text { ing, geoinformatics, cartography }\end{array}$ & 99 \\
\hline $\begin{array}{l}\text { Genetics of animals, cell biology, and } \\
\text { developmental biology }\end{array}$ & 93 \\
\hline $\begin{array}{l}\text { Geochemistry, mineralogy, and crystal- } \\
\text { lography }\end{array}$ & 90 \\
\hline Computer science & 89 \\
\hline Cell biology & 85 \\
\hline $\begin{array}{l}\text { Animal ecology, studies of biodiversity } \\
\text { and ecosystems }\end{array}$ & 84 \\
\hline Neurology & 82 \\
\hline Geology and paleontology & 80 \\
\hline
\end{tabular}

was noted during the global COVID-19 pandemic. Acting in accordance with the Budapest Open Access Initiative, the Berlin Declaration on Open Access to Scientific and Humanitarian Knowledge, as well as relying on previous documents of international organizations, Russia adopted the Declaration on Uniting the Efforts of the Scientific Community in the Fight against COVID-19 [4], which was signed by many publishing houses, libraries, and universities in order to counteract the spread of inaccurate information on the topic of the new coronavirus infection, as well as to facilitate the prompt provision of the scientific community and society as a whole with up-to-date information and materials about it.

In 2020, several initiative projects of publishers and scientific organizations were created for the prompt publication of works related to COVID-19, with a prerequisite for the availability of data [5-7]. Publishers are committed to facilitating the exchange of information reflected in COVID-19 documents in accordance with FAIR principles, working with FAIRsharing, Research Data Alliance and Force11 through the joint RDA/Force11 FAIR sharing working group (for example, providing recommendations for relevant repositories and using appropriate data standards and metadata), and aim to ensure the openness of all peerreviewed scientific publications related to the coronavirus outbreak, as well as the availability of raw data through preprint services or platforms that make articles open before peer review. These initiatives facilitate the rapid exchange of interim and final research results related to COVID-19, as well as the protocols and standards used for data collection, with a significant impact on the science information ecosystem.

The open science movement in its various forms is changing the information ecosystem itself of open science in terms of differences in disciplines and branches of knowledge, regional specifics and prevalence, expanding the range of formats, types of publications, data, and results. Open access resources are reflected in the information systems of publishing houses, vendors, news agencies, scientific and educational institutions, and libraries. Open access to information is of great importance for the formation of a knowledge space, in the construction of which the main role belongs to publishing houses, libraries, and educational institutions [8].

In the context of the development of a modern information ecosystem associated with the ideas of open access, traditional social institutions and mechanisms are being modified, the market of information resources and services is changing, and new rules, conditions, and prospects for the development of the scientific field of activity are being set. "The information society as a multidimensional, complex contradictory phenomenon generated by new high-tech technologies, a new type of communication, new opportunities, requires a thorough revision of the 
existing methods of organization, existing social institutions, reform of the usual types of communication, the transition to innovative management technologies" [9, p. 9]. According to analysts of The Wall Street Journal (2014 review "Good bye, Berlin"), open access did not harm large publishers; everyone needs it: librarians, to solve the problems of the journal crisis; scientists, to increase the level of citations and facilitate the dissemination of knowledge; economists, because it opens up access to new knowledge and technologies for small and medium-sized enterprises; political activists, as a way to reduce the superprofits of capitalists; and activists from developing countries, as a way to prepare doctoral dissertations in these countries [10].

These factors determine the need for a comprehensive scientific analysis of the activities of various social institutions, in particular, libraries, traditionally aimed at supporting, presenting, and promoting the results of scientific research in a unified information ecosystem of knowledge.

\section{A CONCEPTUAL FRAMEWORK FOR THE ROLE OF THE SCIENTIFIC LIBRARY IN OPEN SCIENCE}

In the documents of the European Commission, Organization for Economic Cooperation and Development (OECD), International Federation of Library Associations and Institutions (IFLA), other acts of international and national levels, the professional community has designated and recognized the role of scientific libraries in open science [11-15]. Libraries adapt to the external open information environment, reflecting open access resources in their catalogs and databases. For example, the Online Computer Library Center (OCLC), in cooperation with Europeana collections, HATHI Trust, DOAJ (Directory of Open Access Journals), DOAB (Directory of Open Access Books), etc., provides searching for open access resources through the WorldCat directory (https://www.worldcat.org/).

The International Federation of Library Associations and Institutions (IFLA) has recognized open access as a key issue on its information agenda, as evidenced by the work of librarians in ICT infrastructure development, service delivery, and capacity building through information literacy and security programs $[11,16]$. The open access movement for scientific literature is based on the conviction that scientific and technological information is the most important global public good that should be freely available to all.

At the same time, the existing technologies for supporting open science in libraries, which occupy an important place in the information market of resources and services, are still fragmented; there is no systematic understanding of the strategies and methods for the development of information, bibliographic and reference services, and various resources that allow a comprehensive approach to effectively provide researchers with the necessary infrastructure and services. Thus, the purpose of our research is to develop conceptual approaches to the functioning of a scientific library, contributing to the creation of an effective information and communication infrastructure for supporting open science, managing scientific content, providing open access to information and data, providing high-quality information services in the research life cycle based on an analysis of the existing international experience, the prospects for the development of open science in Russia, and systematization of existing and new tools and their implementation in the framework of cooperation of library specialists with research teams.

It should be noted that these issues continue to be relevant, considering the increase in the interest of researchers in the topic as evidenced by the results of issuing documents to the Scopus database.

Open access issues continue to be discussed in the library community. In the period from 2012 to 2021, the number of publications reflected in the Scopus database almost tripled (Fig. 2). Analysis of the species structure of the stream on the topic "Libraries and Open Access" (a total of 2018 documents based on the search results in the Scopus database from 2012 to 2020) revealed the following distribution of the share of publications by type of publication: articles, 1534; reviews, 150; conference proceedings, 144; and chapters from books, 106. Articles of serial publications occupy a significant place in the species structure of the document flow. An analysis of the repertoire of professional journals reflecting open access topics in libraries is presented in Table 4: more than 11 journals published 20 articles on the topic, the leader was the magazine Library Philosophy and Practice.

The main problems of the articles are connected with the study of the problems of development of business models of access to open content [17, 18] and legal issues governing the open science movement; organization of user service; indexing in databases and publishing systems; distribution, search and access; payment for articles [19]; generation and use of open access repositories [20]; research data management and the role of librarians as collaborators and digital curators [21, 22]; etc. The results of the bibliometric analysis of the document flow indicate a steady increase in publications on the topic considered here, the dominance of the number of publications in journals (the rating is built by their number in publications in library and information sciences), which confirms the relevance and need for a comprehensive study of the role of libraries in the development of open science.

As the priorities of academic institutions evolve, the role of research libraries is changing. They become key partners in the long-term future of open science, 


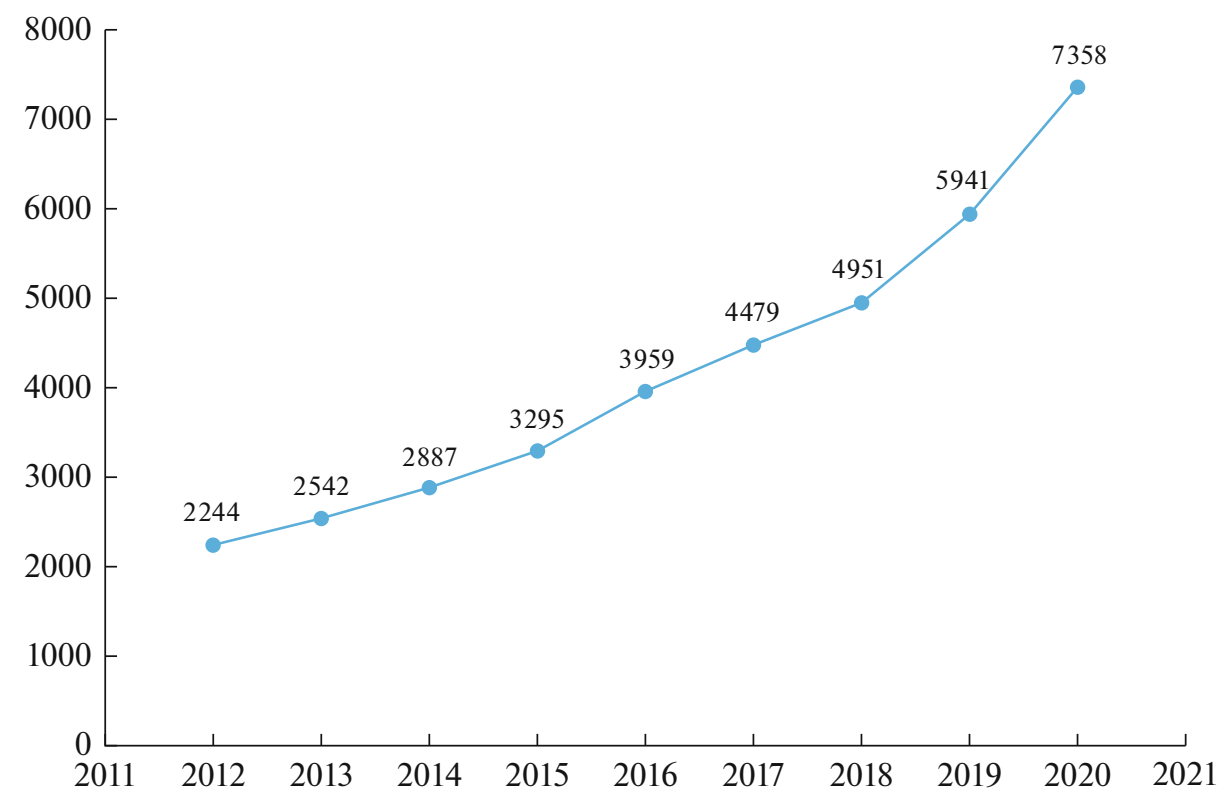

Fig. 2. Dynamics of publications on topic of Library and Open Science (subject area of social sciences) in Scopus (2012-2020).

because they have an idea of what their founders want [23]. Over the years, the relationship between open science and research libraries has grown significantly. Academic librarianship has evolved into a distinct area with its own set of goals and commitments in the academic community [23, 24] developed by mechanisms that allow universities and scientific organizations to work more efficiently in the area of production and exchange knowledge, data, thereby promoting institutional research [25-27], service delivery from teaching individual information literacy to data mining [27], "embedding" librarians in the research process

Table 4. List of periodicals in which more than 20 articles were published on the topic of Library and Open Science in 2012-2020

\begin{tabular}{r|l|c}
\hline No. & \multicolumn{1}{|c|}{ Edition name } & $\begin{array}{c}\text { Number } \\
\text { of publications }\end{array}$ \\
\hline 1 & Library Philosophy and Practice & 103 \\
2 & Insights: The UKSG Journal & 62 \\
3 & Serials Librarian & 59 \\
4 & Liber Quarterly & 48 \\
5 & Evidence Based Library and Informa- & 43 \\
& tion Practice & 40 \\
6 & Electronic Library & 40 \\
7 & Serials Review & 39 \\
9 & VÖB Mitteilungen & 34 \\
10 & Journal of Academic Librarianship & 32 \\
11 & Interlending \& Document Supply & 29 \\
\hline
\end{tabular}

and joint research [27-29], participation in the creation and maintenance institutional repositories [30, 31], conducting altmetric studies [32, 33], creation of alternative editions (loading research results into repositories [20]), etc.

Content analysis of publications on the problem allowed us to conclude that open access as a new model for the dissemination of scientific information affects the change in the role of academic libraries in the information support of science and allows us to determine promising directions for their development [34]. For libraries, both key functions of open access systems are important: as a means of disseminating and delivering information (in this case, it is the formation of repositories on the basis of university libraries) and as a provider of information for readers and users of the library (in this case, it is help in navigating and providing library readers with open access journals, as well as materials from repositories) $[8,10]$. In libraries, "new" specialists appear: the data steward, data manager, metadata manager, research data management librarian, data curator, archivist/digital data scientist, content curator, co-investigator, collaborator, digital/information intermediary, digital curator, knowledge engineer, subject librarian, etc.

Below are just a few of the new specializations for librarians in research libraries, indicating that the open science that librarians are influencing allows them to at the same time demonstrate new and more important roles, given the appropriate competencies. Basic librarian skills in finding, collecting, organizing, evaluating, and disseminating information have a major impact on the creation, development, and management of digital content and open access resources. 
However, in the context of the development of open science, the competence of librarians is significantly expanding [35], new tasks and requirements for their knowledge and skills appear [36, 37]. For example, when working in an institutional repository, knowledge of software, project planning and management, collection definitions, metadata guides, presentation analysis, and author training are essential [38].

\section{THE OPPORTUNITIES AND PROSPECTS OF LIBRARY ACTIVITIES IN THE CONTEXT OF OPEN SCIENCE}

In the cycle of production, exchange, and dissemination of information and knowledge libraries play an important role as they navigate information resources, conduct consultations, search for information, training, subject support, resource management, and monitoring. It seems that, by choosing a clear strategy for the development of libraries (mostly scientific) in the conditions of a modern information ecosystem associated with the ideas of open science, libraries have every chance of being in demand by users.

Information support on open access resources, which is carried out by librarians, allows the user to navigate open scientific content: Open Access Journals Directory (http://doaj.org); Open Access Repository Directory (http://www.opendoar.org); Data repository directory [re3data] (http://service.re3data.org); aggregators for various OpenAIRE open source resources (https://www.openaire.eu), Zenodo (https://zenodo.org), etc.; open magazine aggregators-Paperity (http://paperity.org), CyberLeninka (http://cyberleninka.ru), a number of projects of the NEICON nonprofit partnership (the elpub magazine platform, the preprints.ru preprint server, and the national aggregator of open repositories (NORA)). In addition, open source resources are reflected in library-generated catalogs and databases, for example, through the WorldCat catalog.

Librarians have the ability to recommend existing services or create their own services for managing research data that provide seamless access to data and platforms that support open science and cover the entire cycle from searching to storage in repositories, management (registration, access and efficient use of computing services, services for annotation, and data discovery based on metadata), analysis (sets of computing tools and applications for various fields of knowledge, for example, DARIAH Science Gateway in Arts and Humanities or WeNMR Package for Structural Biology), exchange, and reuse in different scientific fields.

Librarians already offer guidance, training and services in the following areas: providing information at all stages of the research life cycle, opportunities and requirements for financing scientific foundations and publishing houses, bibliography and data manage- ment, creation and use of metadata, definition of open research methods and tools for analysis, data exchange, publication of results, data citation, licensing and other intellectual property issues, preparation of data for deposition and long-term storage, etc.

Library specialists give advice on types of open access, which are differentiated depending on their availability and cost: Libre OA (read and reuse articles), Gratis OA (read only articles), Gold OA (journals with direct OA), Green OA (journals with self-archiving permission), Hybrid OA (OA after payment of an article processing fee), Delayed OA (OA after the time of embargo), academic social networks (online communities), and Black OA (illegal pirate sites) [39, 40].

Librarians can contribute to the acquisition of skills and knowledge in such subject areas as options for publishing materials in the open access, use of open licenses (for example, $\mathrm{CC} 0$ or $\mathrm{CC}-\mathrm{BY}$ ), sharing preprints (for example, in OSF, arXiv, or bioRxiv), shared codes (for example, on GitHub with a GNU/MIT license), data exchange (for example, in Dryad, Zenodo), altmetric assessment methods, etc. Open science seminars, workshops, conferences, and continuing education programs organized by a library will help to raise awareness of open science concepts, terms, models for promoting research results, funding agency policies and principles of data sharing, tools and resources of open science, and research data management, to develop open access publishing skills in the context of open science, to stimulate the use of digital infrastructures, and to ultimately contribute to the implementation of the open science paradigm.

Developing the directions of library activity in the context of open science, one cannot but take note of possible problems: (1) the declared functionality cannot be performed without the appropriate skills, knowledge and professional competencies of librarians; (2) incomplete/inaccurate metadata of information resources of open access and unreliability of information resources of open access [41]; (3) insufficient awareness of researchers about open access and a low level of their information literacy; (4) financial restrictions for publishing open access; (5) undeveloped infrastructure for integrating open access information resources into library catalogs and databases; and (6) ignorance of legal issues and information needs of users with organizational and infrastructural support of open science, etc. The development of these areas and the solution of these problems will allow the library to become one of the key actors in the creation and maintenance of the infrastructure of open science.

\section{CONCLUSIONS}

The open science movement in its various forms is reshaping the information ecosystem and represents a promising direction for libraries, which have always 
played an important role in the cycle of production, exchange, and dissemination of information and knowledge. The growing number of open access resources, open science initiatives, and projects is driving a significant change in the way libraries work, creating electronic resources based on open access publications and data, providing guidance on access to information and data, managing subscription budgets and generating updated reporting on resource use, development of services to support the entire research life cycle, and subject-oriented training of scientists and specialists.

\section{CONFLICT OF INTEREST}

The author declares that she has no conflicts of interest.

\section{REFERENCES}

1. Consolidated roadmap for a possible UNESCO recommendation on open science. https://unesdoc.unesco.org/ark:/48223/pf0000369699. Cited August 4, 2021.

2. Redkina, N.S., Current trends in research data management, Sci. Tech. Inf. Process., 2019, vol. 46, no. 2, pp. 53-58.

https://doi.org/10.3103/S0147688219020035

3. Collaboration and community: Transition to open access, 2018. https://www.youtube.com/watch? $\mathrm{v}=\mathrm{rBrkx}-$ 7aUWdI. Cited August 4, 2021.

4. Declaration on uniting the efforts of scientific community in COVID-19 response. https://covid19.neicon.ru/. Cited August 4, 2021.

5. COVID-19 publishers open letter of intent - Rapid review. https://oaspa.org/covid-19-publishers-open-letterof-intent-rapid-review. Cited August 4, 2021.

6. Sharing research data and findings relevant to the novel coronavirus (COVID-19) outbreak. https://wellcome. org/press-release/sharing-research-data-and-findingsrelevant-novel-coronavirus-ncov-outbreak. Cited $\mathrm{Au}-$ gust 4, 2021.

7. Publishers make coronavirus (COVID-19) content freely available and reusable. https://wellcome.org/ press-release/publishers-make-coronavirus-covid-19content-freely-available-and-reusable. Cited August 4, 2021.

8. Shraiberg, Ya.L., Generation of unified knowledge space based on network information infrastructure under conditions of establishments in development of modern digital economy: Annular report of the Fourth Int. Professional Forum Krym-2018, Nauch. Tekh. Bibl., 2018, no. 9, pp. 4-76. https://digitalcommons.unl.edu/cgi/viewcontent.cgi?Article $=6178 \&$ context=libphilprac. Cited August 4, 2021.

9. Surin, A., Training of new generation of managers: On the path towards paradigm, Vyssh. Obraz. Rossii, 2006, no. 9 , pp. 7-14.

10. Zemskov, A.I., Sci-tech libraries' routes to open access (IATUL-2018), Nauch. Tekh. Bibl., 2019, no. 1, pp. 63-79.
11. IFLA statement on open access, 2011. https://www.ifla. org/publications/node/8890. Cited August 4, 2021.

12. UNESCO recommendation on open educational resources, 40 C/32 Annex, Paris: UNESCO, 2019. http://opening-up.education/wp-content/uploads/2019/ 12/RECOMMENDATION-CONCERNING-OPENEDUCATIONAL-RESOURCES.pdf. Cited August 4, 2021.

13. European Commission, Study on open science. Impact, implications and policy options, Brussels: European Commission, 2015. https://ec.europa.eu/research/ innovation-union/pdf/expert-groups/rise/stu-dy_on_ open_science-impact_implications_and_policy_optionssalmi_072015.pdf. Cited August 4, $202 \overline{1}$.

14. OECD, Making open science a reality, OECD science, technology and industry policy papers, Paris: OECD Publishing, 2015, no. 25. https://doi.org/10.1787/5jrs2f963zs1-en

15. Open Access Australasia. https://aoasg.org.au/. Cited August 4, 2021.

16. IFLA (International Federation of Library Associations and Institutions), IFLA statement on libraries and intellectual freedom, 2015. https://www.ifla.org/ publications/ifla-statement-on-libraries-and-intellectualfreedom. Cited August 4, 2021.

17. Ahmed, M.H. and Suleiman, R.J., Academic library consortium in Jordan: An evaluation study, J. Acad. Libr., 2013, vol. 39, no. 2, pp. 138-143.

https://doi.org/10.1016/j.acalib.2012.09.021

18. Horava, T. and Ward, M., Library consortia and article processing charges: An international survey, Ser. Rev., 2016, vol. 42, no. 4, pp. $280-292$.

https://doi.org/10.1080/00987913.2016.1237928

19. Pereira, R. and Franco, M., Library as a consortium perspective: A systematic literature review, J. Libr. Inf. Sci., 2020, vol. 52, no. 4, pp. 1126-1136.

https://doi.org/10.1177/0961000620904754

20. Bankier, J.-G. and Perciali, I., The institutional repository rediscovered: What can a university do for open access publishing?, Ser. Rev., 2008, vol. 34, no. 1, pp. $21-26$.

https://doi.org/10.1080/00987913.2008.10765147

21. Cox, A.M., Kennan, M.A., Lyon, L., and Pinfield, S., Developments in research data management in academic libraries: towards an understanding of research data service maturity, J. Assoc. Inf. Sci. Technol., 2017, vol. 68 , no. 9 , pp. $2182-2200$.

https://doi.org/10.1002/asi.23781

22. Wilkinson, M.D. et al., The FAIR Guiding Principles for scientific data management and stewardship, Sci. Data, 2016, vol. 3, p. 160018.

https://doi.org/10.1038/sdata.2016.18

23. Ogungbeni, J.I., Obiamalu, A.R., Ssemambo, S., and Bazibu, C.M., The roles of academic libraries in propagating open science: A qualitative literature review, Inf. Dev., 2018, vol. 34, no. 2, pp. 113-121. https://doi.org/10.1177/0266666916678444

24. Jaguszewski, J.M. and Williams, K., New roles for new times: Transforming liaison roles in research libraries. Report prepared for the Association of Research Libraries, 2013. http://www.arl.org/storage/documents/ 
publications/nrnt-liaison-roles-revised.pdf. Cited August 4, 2021.

25. Wilson, K., Neylon, C., Brookes-Kenworthy, C., Hosking, R., Huang, C.-K., Montgomery, L., and Ozaygen, A., 'Is the library open?': Correlating unaffiliated access to academic libraries with open access support, Liber $Q ., 2019$, vol. 29, no. 1, pp. 1-33.

https://doi.org/10.18352/lq.10298

26. Webster P. Integrating discovery and access to Canadian data sources. Contributing to academic library data services by sharing data source knowledge nation wide, IFLA. http://library.ifla.org/2514/1/248-websteren.pdf. Cited August 4, 2021.

27. Chen, Q., Zhong, H., Yaqi, S., and Chen, Y., Research on cooperation between the academic library and research team: Taking the life \& medical sciences subject team of Shanghai Jiao Tong University library as an example, IFLA. http://library.ifla.org/2576/1/082chen-en.pdf. Cited August 4, 2021.

28. Cabrera G. and Sambaíno S., Experiencias del bibliotecólogo integrado dentro de los ciclos de investigación en bibliotecas universitarias de Uruguay, IFLA. http://library.ifla.org/2577/1/082-cabrera-es.pdf. Cited August 4, 2021.

29. Corrall, S., Designing libraries for research collaboration in the network world: An exploratory study, Liber $Q ., 2014$, vol. 24 , no. 1 , pp. 17-48. https://doi.org/10.18352/lq.9525

30. Bailey, C.W., The role of reference librarians in institutional repositories, Ref. Serv. Rev., 2005, vol. 33, no. 3, pp. 259-267.

https://doi.org/10.1108/00907320510611294

31. Chang, S.H., Institutional repositories: the library's new role, OCLC Syst. Serv., 2003, vol. 19, no. 3, pp. 77-79. https://doi.org/10.1108/10650750310733199

32. Costa, R., Zahedi, Z., and Wouters, P., Do "altmetrics" correlate with citations? Extensive comparison of altmetric indicators with citations from a multidisciplinary perspective, J. Assoc. Inf. Sci. Technol., 2015, vol. 66, no. 10, pp. 2003-2019.

https://doi.org/10.1002/asi.23309
33. Priem, J., Taraborelli, D., and Groth, P., and Neylon, C., Altmetrics: a manifesto, 2010. http://altmetrics.org/ manifesto/. Cited August 4, 2021.

34. Lakizo, I.G., Siberian scientists' growth of interest in open resources, Tr. Gos. Publ. Nauch.-Tekh. Bibl. Sib. Otd. Ross. Akad. Nauk, 2019, no. 2, pp. 44-49. https://doi.org/10.20913/2618-7515-2019-2-44-49

35. Ghosh, M., Information professionals in the open access era: the competencies, challenges and new roles, Inf. Dev., 2009, vol. 5, no. 1, pp. 31-41. https://doi.org/10.1177/0266666908098075

36. Czerniewicz, L., Power and politics in a changing scholarly communication landscape, Proceedings of the IATUL Conferences, IATUL, Cape Town, 2013. https://docs.lib.purdue.edu/iatul/.

37. Tapfuma, M.M. and Hoskins, R.G., Open science disrupting the status quo in academic libraries: A perspective of Zimbabwe, J. Acad. Libr., 2019, vol. 45, no. 4, pp. 406-412. https://doi.org/10.1016/j.acalib.2019.05.005

38. Allard, S., Mack, T.R., and Feltner-Reichert, M., The librarian's role in institutional repositories: A content analysis of the literature, Ref. Serv. Rev., 2005, vol. 33, no. 3, pp. 325-336. https://doi.org/10.1108/00907320510611357

39. Piwowar, H., Priem, J., Larivière, V., Alperin, J.P., Matthias, L., Norlander, B., Farley, A., West, J., and Haustein, S., The state of OA: a large-scale analysis of the prevalence and impact of Open Access articles, Peer $J ., 2018$, vol. 6, p. e4375. https://doi.org/10.7717/peerj.4375

40. Stracke, C.M., Open science and radical solutions for diversity, equity and quality in research: a literature review of different research schools, philosophies and frameworks and their potential impact on science and education, Radical Solutions and Open Science, Burgos, D., Ed., Lecture Notes in Educational Technology, Singapore: Springer, 2020, pp. 17-37. https://doi.org/10.1007/978-981-15-4276-3_2

41. Sultan, M. and Rafiq, M., Open access information resources and university libraries: Analysis of perceived awareness, challenges, and opportunities, J. Acad. Libr., 2021, vol. 4, no. 4, p. 102367. https://doi.org/10.1016/j.acalib.2021.102367 